\title{
The Implementation of Basic Counseling Technique in Elementary School For Helping The Development and Alleviating Student's Problems in West Pasaman District Education Office
}

\author{
Netrawati \\ Universitas Negeri Padang \\ netrawatiunp07@fip.unp.ac.id \\ Yeni Karneli \\ Universitas Negeri Padang \\ ykarneli@gmail.com \\ Neviyarni S \\ Universitas Negeri Padang \\ sneviyarni@gmail.com
}

\begin{abstract}
Children' Development and Characteristic in elementary school-age are different. Each child is different, Low class students between high class students are different. The students come to school in order to be able to follow the education well. But It will not last forever. The problems that they face come from inability in doing assignment,wish, competition among friends, less motivations to study, less supports from parents and others. Deviant behavior also comes from many forms such as, bothering friend, breaking school's facilities, hard in focusing the attention, often musing, and playing-truant. The puroses of this dedication are : 1) class teachers and subject teachers can make a profgram of leadership and Counseling which is integrated into the lesson with tematic approach. 2) Giving Individual Counseling service to help the development and problems of students in Elementary School. The target of this dedication is subject teachers and class teachers of Elementary school in West Pasaman Regency. The method that is used in this research is Descriptive Quantitative, which describes the real condition. Elementary school teachers have had Basis Counseling skill to help students who have problems at school. 30\% of elementary school teachers have had basis counseling skill to help students' problems at school, and there are still some elementary school teachers who have low Counseling skill.
\end{abstract}


Keywords: basic counseling techniques, development, student problems

\begin{abstract}
Abstrak
Perkembangan dan karakteristik anak pada usia sekolah dasar berbeda-beda. Antara anak yang satu dengan anak yang lainnya berbeda, antara anak kelas rendah dan anak kelas tinggi berbeda. Siswa datang ke sekolah dengan harapan agar bisa mengikuti pendidikan dengan baik.Tetapi tidak selamanya demikian.Berbagai masalah yang mereka hadapi bersumber dari ketidakmampuan mengerjakan tugas, keinginan, persaingan dengan teman, kurang motivasi belajar, kurang dukungan orangtua, dan lain sebagainya. Perilaku menyimpang juga muncul dari berbagai bentuk seperti; suka menganggu teman, merusak alat- alat pelajaran dan fasilitas sekolah,sulit memusatkan perhatian, sering termenung, dan bolos pada jam belajar.Tujuan pengabdian ini adalah; 1) guru kelas dan guru mata pelajaran dapat membuat program bimbingan dan konselig yang diintegrasikan kedalam mata pelajaran dengan pendekatan tematik, 2) memberikan layanan konseling individual untuk membatu perkembangan siswa dan permasalahanpermasalahan siswa sekolah dasar. Sasaran dalam pengabdian ini adalah guru mata pelajaran dan guru kelas Sekolah Dasar di Kabupaten Pasaman Barat. Metode yang digunakan penelitian ini deskripif kuantitatif, yang mengambarkan keadaan seauia dengan realita yang ada. Guru sekolah dasar sudah memiliki keterampilan dasar konseling yang cukup memadai untuk membantu siswa yang bermasalah di sekolah. Sebanyak 30\% guru sekolah dasar sudah memiliki keterampilan dasar konseling untuk membantu permasalahan siswa di sekolah dan masih ada sebagian kecil guru sekolah dasar yang memiliki ketermpilan konseling yang rendah.

Kata Kunci: teknik dasar konseling, perkembangan, masalah siswa
\end{abstract}

\title{
Pendahuluan
}

Pelayanan bimbingan dan konseling perlu diselenggarakan di Sekolah Dasar agar pribadi dan segenap potensi yang dimiliki pesertadidik dapat berkembang secara optimal. Pelayanan tersebut disesuaikan dengan pendidikan di sekolah dasar, terutama yang menyangkut kekhususan peserta didik, tujuan pendidikan serta kemampuan guru kelas sebagai pelaksana bimbingan. Demikian pula guru diharapkan dapat memahami hambatan dan permasalahan yang dialami peserta didik, sehingga dapat menindaklanjuti dari permasalahan yang dialami peserta didik.

Siswa atau peserta didik sekolah dasar berada pada usia emas, 
perkembangannya merupakan masa membangun pengalaman belajar awal yang bermakna. Pada usia ini peserta didik berada pada masa peka dalam mengembangkan seluruh potensi dan kecerdasan otak mencapai80\%. Guru bimbingan dan konseling atau konselor dan guru kelas/mata pelajaran memiliki peran penting untuk memberikan ransangan yang tepat sehingga sel-sel otak berkembang dan berfungsi secara optimal untuk mendukung kematangan semua aspek perkembangan. Perkembangan yang optimal pada usia di Sekolah Dasar menjadi fondasi yang kuat bagi perkembangan pada tahap-tahap berikutnya. Pengalaman belajar awal yang menyenangkan dan bermakna bagi anak mendorong anak untuk memahami fungsi belajar bagi dirinya dan memotivasi untuk menjadi pembelajar sepanjang hayat.

Pelayanan bimbingan dan konseling merupakan bagian integral dari program pendidikandi sekolahyang seyogianya dilakukan oleh guru bimbingan dan konseling atau konselor yang memiliki kompetensi yang diamanatkan dalam Peraturan Menteri Pendidikan Nasional Nomor 27 Tahun 2008 tentang Stkonselor $\mathrm{r}$ Kualifikasi Akademik dan Kompetensi Konselor. Kompetensi tersebut meliputi kompetensi pedagogik, kompetensi kepribadian, kompetensi sosial dan kompetensi profesional. Idealnya setiap sekolah dasar memiliki guru bimbingan dan konseling atau konselor. Guru bimbingan dan konseling atau konselor saling bahu-membahu dengan guru kelas dan guru mata pelajaran dalam membantu peserta didik mencapai perkembangan optimal. Pada kondisi belum ada guru bimbingan dan konseling atau konselor dapat ditugaskan guru kelas terlatih untuk menyelenggarakan layanan bimbingan dan konseling.

Guru bimbingan dan konseling atau konselor di Sekolah Dasar dapat diangkat dengan cakupan tugas pada setiap sekolah atau ditingkat gugus sekolah untuk membantu guru mengembangkan potensi dan mengentaskan masalah peserta didik. Guru bimbingan dan konseling atau konselor ditingkat gugus berkantor di sekolah induk yang ditetapkan oleh Dinas Pendidikan Kabupaten/Kota. Dalam kondisi sekolah induk tidak memiliki ruang yang cukup, maka berkantor di Unit Pelaksana Teknis Daerah (UPTD) Pendidikan atau unit pendidikan yang setingkat. ${ }^{1}$

Penyelenggaraan pendidikan yang bermutu dan efektif adalah mengintegrasikan tiga komponen system pendidikan yang meliputi komponen manajemen dan kepemimpinan, komponen pengajaran, serta komponen bimbingan dan konseling. Ketiga komponen tersebut memiliki wilayah garapan sendiri-sendiri yang saling melengkapi dalam upaya tercapainya tujuan pendidikan nasional. Dalam Peraturan Menteri Pendayagunaan Aparatur Negara Nomor 16 Tahun 2009 tentang Jabatan Fungsional Guru dan Angka

\footnotetext{
${ }^{1}$ Kementrian Pendidikan dan Kebudayaan. (2014). Permendikbud No 111 Tahun 2014 tentang Penyelengaraan Bimbingan dan Konseling di Sekolah Dasar dan Menengah, Direktorat Jendral Guru dan Tenaga Kependidikan: Jakarta
} 
Kreditnya disebutkan bahwa jenis guru berdasarkan sifat, tugas, dan kegiatannya meliputi guru kelas, guru mata pelajaran serta guru bimbingan dan konseling/konselor.

Pendekatan dalam membantu permasalahan siswa bisa dilakukan dengan pendekatan yang lebih spesifik yaitu pendekatan konseling analisis transaksional. Untuk membantu permasalahan siswa disekolah dasar juga bisa dilakukan dengan pendekatan konseling transaksional. ${ }^{2}$

Tujuan dari penulisan ini adalah 1) menggambarkan kegiatan guru kelas dan guru mata pelajaran dalam membuat program bimbingan dan konseling yang diintegrasikan kedalam mata pelajaran dengan pendekatan tematik. Dalamperencanaanprogrambimbingkonselor nkonseling diharapkan guru kelas dan guru mata pelajaran dapat membuat program dengan duatahapan,yaitu(a) tahap persiapan(preparing) dan (b) tahap perancangan (designing),. 2) menggambarkan pelayanan konseling individual yang dilksnakan guru kelas dan guru mata pelajaran untuk membatu perkembangan siswa dan permasalahanpermaslahan siswa sekolah dasar.

\section{Metode Penelitian}

Penelitian ini bersifat deskriptif, yaitu penelitian untuk menyelidiki keadaan, kondisi atau hal lain-lain yang sudah disebutkan serta hasilnya dipaparkan dalam bentuk laporan penelitian. ${ }^{3}$ Populasi penelitian adalah guru sekolah dasar di kabupaten Pasaman Barat. Sampel penelitian 23 orang guru sekolah dasar.

\section{Kajian Teori}

\section{Hubungan Awal Dalam Konseling Yang Dilaksanakan Guru Sekolah Dasar}

Hubungan dalam konseling adalah hubungan yang membantu. Artinya konselor menciptakan suasana dan mempergunakan berbagai cara agar konseli merasa terbantu. Konselor berusaha membantu konseli agar potensinya berkembang secara optimal, mandri, dan berbahagia. Shetzer dan Stone berpendapathubungan konseling merupakan interaksi seorang dengan orang lain yang dapat menunjang dan memudahkan secara positif bagi perbaikan orang tersebut.

Pada prinsipnya hubungan konseling, lebih menekankan pada bagaimana

\footnotetext{
${ }^{2}$ Netrawati, Khairani, Yeni Karneli. (2018). Upaya Guru BK untuk Mengentaskan Masalah-masalah Perkembangan Remaja dengan Pendekatan Konseling Analisis Transaksional. Jurnal Islamic Counseling; Bimbingan Konseling Islam., Vol. 2. 1.

${ }^{3}$ Suharsimi Arikunto. (2010). Prosedur Penelitian Suatu Pendekatan Praktis. Jakarta: Rbineka Cipta.
} 
konselor atau guru bimbingan dan konseling menciptakan situasi kondusif bagi keterbukaan, kesukarelaan, dan kepercayaan konseli, serta kelancaran proses konseling. Pencapaian hubungan konseling yang kondusif memerlukan empat kodisi inti yang perlu dipertahankan oleh konselor atau guru bimbingan dan konseling, yaitu menunjukkan sikap yang asli (genuine, congruence), penerimaan tanpa syarat dengan penuh hormat (unconditional positive regard, accepatance dan respec), pemahaman empati yang tepat dan konkrit (congoretness). ${ }^{4}$ Pernyataan Komala Sari senada dengan hipotesis Rogers yang menyatakan sikap konselor, yaitu ketulusan, kehangatan, penerimaan yang positif, dan empati yang akurat akan membentuk kondisi yang diperlukan bagi keefektifan konseling. ${ }^{5}$

Membangun hubungan dijadikan langkah pertama dalam konseling, karena klien dan konselor harus saling mengenal dan menjalin kedekatan emosinal sebelum sampai pada pemecahan masalahnya. Pada tahapan ini, konselor harus menunjukkan bahwa ia dapat dipercaya dan kompeten dalam menangani masalah klien. Menurut Willis dalam buku Dasar-dasar Konseling dan Psikoterapi milik Namora Lubis Lumongga, mengatakan bahwa dalam hubungan konseling harus berbentuk a working relationship yaitu hubungan yang berfungsi, bermakna, dan berguna. Konselor dan klien saling terbuka satu sama lain tanpa ada kepura-puraan. Selain itu, konselor dapat melibatkan klien terus menerus dalam proses konseling. Keberhasilan pada tahap ini menentukan keberhasilan langkah konseling selanjutnya.

Membangun hubungan konseling juga dapat dimanfaatkan konselor untuk menentukan sejauh mana klien mengetahui kebutuhannya dan harapan apa yang ingin ia capai dalam konseling. Konselor juga dapat meminta klien agar berkomitmen menjalani konseling dengan sungguh-sungguh.Meminta kesediaan klien melakukan komitmen perlu dilakukan untuk mencegah klien menghindar atau menolak komitmen yang telah disepakati.

\section{Konselor Sebagai Pribadi}

Kepribadian seorang konselor atau guru bimbingan dan konseling juga turut menentukan keberhasilan proses konseling. Menurut Wills kualitas pribadi konselor lebih menentukan kefektifan konseling dibandingkan dengan pendidikan dan pelatihan yang diperoleh. Dimensi kepribadian yang harus dimiliki konselor adalah spontanitas, fleksibelitas, kensentrasi, keterbukaan, stabilitas emosi, berkeyakinan akan kemampuan untuk berubah, komutmen pada rasa kemanusiaan, kemauan membantu konseli mengubah lingkungannya, pengetahuan konselor, dan totalitas. ${ }^{6}$

${ }^{4}$ Komalasari, G., Eka, W., \& Karsih. (2011). Teori dan Teknik Konseling. Jakarta: Indeks.

${ }^{5}$ Corey, M. S., Corey, G., \& Corey, C. (2009). Groups: Process and practice (8th ed.). PacificGrove, CA: Brooks/Cole.

${ }^{6}$ Sofyan S. Willis. 2004.Konseling Individual; TeoridanPraktek. Bandung : Alfabeta, Hal 161 
Untuk dapat melaksanakan peranan profesional yang unik sebagaimana tuntutan profesi, konselor profesional harus memiliki pribadi yang berbeda dengan pribadi-pribadi yang bertugas membantu lainnya.Konselor dituntuk memiliki pribadi yang lebih mampu menunjang keefektifan konseling. Keberhasilan dalam konseling lebih bergantung pada kualitas pribadi konselor ketimbang kecermatan Keterampilan .Namun bukan berarti bahwa keterampilan konselor tidak penting.Karena keterampilan juga dapat meningkatkan kualitas pribadi konselor pada taraf yang lebih tinggi. Ciri kekhasan konselor : kesadaran akan diri dan nilai-nilai, kesadaran akan pengalaman budaya, kemampuan menganalisis perasaan sendiri, kemampuan menjadi "teladan" dan "orang yang berpengaruh", altruisme (kesediaan berkorban untuk kepentingan atau kebahagiaan orang lain, penghayatan etik yang kuat, dan tanggung jawab.

Persamaan pribadi antara konselor dengan klien merupakan hal yang penting dalam konseling. Kualitas lahiriah dari seorang konselor adalah menawan hati, memiliki kemampuan bersikap tenang ketika bersama orang lain, memiliki kapasitas untuk berempati, dan karakteristik-karakteristik lain yang memiliki makna yang sama. Kualitas tersebut tidak seluruhnya bawaan sejak lahir, melainkan dapat dicapai dan diusahakan lewat proses belajar.

Pribadi seorang konselor yang seimbang dapat membantu dirinya dalam men-jalankan tugas sebagai seorang konselor yang benar.Tugas seorang konselor adalah memberikan bantuan kepada klien (konseli) untuk menyelesaikan problem yang mengganggu. Konseling juga dimaksudkan untuk membantu konseli mengembangkan beragam cara yang lebih positif untuk menyikapi hidup. Konseling, pada umumnya bertujuan memecahkan masalahmasalah konseli, atau menumbuhkan kekuatan mereka dalam menyikapi hidup.

Dalam praktik konseling, terdapat tiga keterampilan yang wajib dikuasai oleh seorang konselor, yaitu:

a. Keterampilan Antarpribadi, adalah semua keterampilan yang dibutuhkan untuk membangun relasi dengan klien (konseli). Sehingga, klien dapat terlibat dalam proses konseling.

b. Keterampilan Intervensi, adalah kemampuan konselor melibatkan klien (konseli) dalam pemecahan masalah sesuai dengan cara dan strategi yang diusulkan oleh berbagai aliran konseling.

c. Keterampilan Integrasi, mengacu kepada kemampuan konselor untuk menerapkan strategi pada situasi khusus, sambil mengingat konteks budaya dan sosial-ekonomi klien (konseli). Konseling tidak dapat dipraktikkan tanpa memperhitungkan konteks budaya dengan sungguh-sungguh.

\section{Keterampilan Dasar Konseling}

1. Perilaku Attending

Perilaku attending merupakan perilaku yang menghampiri konseli yang 
mencakup komponen kontak mata, bahasa badan, dan bahasa lisan. ${ }^{7}$ Perilaku attending yang baik dari seorang konselor meliputi bagaimana konselor menyiapkan diri, bersikap, berperilaku, mendengarkan, dan memberikan perhatian secara penuh pada konseli. Perilaku attending akan menciptakan suasana yang aman dan nyaman seta meningkatkan harga diri konseli. Konselor menaruh hormat terhadap konseli sebagai pribadi serta menunjukkan perhatian dan minat terhadap apa yang dikatakan oleh konseli. Implikasinya, perilaku attending akan memudahkan konseli mengekspresikan perasaan dengan bebas, suka rela dan terbuka. Perilaku attending meliputi perilaku non verbal yang meliputi bahasa badan dan kontak mata serta perilaku verbal atau bahasa lisan.

Menerima klien berkaitan dengan rasa hormat terhadap individu sebagai pribadi yang memiliki harga diri. Ada dua komponen dal hal menerima klien, yaitu :

a. Kemampuan konselor dalam hal menerima kebenaran bahwa individu/klien berbeda satu sama lain, demikian juga cara-cara dan perilaku yang ditampilkan.

b. Perwujudan diri yang berlangsung dalam pengalaman, bahwa setiap orang memiliki pola yang kompleks dalam berbuat, merasa, bersikap, dan cara betanggung jawab atas diri klien.

Kualitas hubungan dalam konseling juga sangat dipengaruhi oleh kepribadian konselor itu sendiri. Dalam memulai hubungan konseling, konselor hendaknya bersikap:

a. Luwes, yaitu bebas Dallam berbicara dan tidak kaku

b. Hangat, yaitu salamnya dan senyumnya dari penerimaan konselor terhadap klien

c. Dapat menerima orang lain (apa adanya) tidak berpura-pura

d. Terbuka, yaitu konselor menerima klien dan meluangkan waktu kepada klien untuk konseling

e. Menghargai orang lain

f. Tidak mau menang sendiri

g. Penuh perhatian

h. Bijaksana

\section{Mendengar Aktif}

Mendengarkan secara aktif memerlukan mendengar terhadap isi, suara dan bahasa tubuh dari orang yang bicara. Selain itu melibatkan mengkomunikasikan pesan terhadap orang yang berbicara bahwa mendengar benar-benar sedang memperhatikan apa yang dibicarakan. Konselor harus dapat mengidentifikasi unsur pesan: apa, mengapa, kapan, dimana, siapa, dan bagaimana. 
Mendengar merupakan keterampilan penting dalam proses konseling. Dan keterampilan mendengarkan sangat diperlukan serta dilengkapi dengan keterampilan dasar lain yang tidak boleh ditinggalkan. Mendengar dalam keterampilan ini adalah mendengar dengan tepat dan mengingat apa yang konseli katakana dan bagaimana mengatakannya. Mendengar yang tepat memungkinkan konselor merumuskan tanggapan yang tepat tentang perasaan dan pikiran konseli. Cara mendengarkan yang baik mencakup:

a. Memelihara perhatian penuh dengan terpusat kepada konseli. Mendengarkan yang seperti ini adalah mendengarkan sekaligus memusatkan konsentrasi pada tiap-tiap kata yang diucapkan oleh konseli.

b. Mendengarkan segala sesuatu yang dikatakan oleh konseli. Pada hal ini, konselor perlu merekam dengan baik segala sesuatu yang diungkapkan konseli dalam proses konseling, agar dapat mengkomunikasikan dengan tepat pernyataan-pernyataan yang diungkapkan oleh konseli.

c. Mendengarkan keseluruhan pribadi konseli (kata-katanya, perasaan dan perilakunya). Memahami pesan baik verbal maupun nonverbal dari diri konseli. Karena tidak hanya dari pesan verbal saja konselor dapat memahami keseluruhan pribadi konseli, sikap konseli juga dapat dilihat dari pesan nonverbal yangdisampaikan.

Mendengarkan adalah proses aktif menghadiri dengan sedikit atau tanpa verbal. Ini mungkin tampak aneh, di pertama untuk memberikan keunggulan untuk mendengarkan sebagai suatu teknik konseling. Namun, semua sistem keterampilan membantu memberi mendengarkan adalah tempat yang menonjol. Ini adalah keyakinan kami bahwa mendengarkan terapeutik adalah teknik bahwa mus dipelajari. Konselor awal sering merasa bahwa ketika jeda panjang mereka tidak melakukan cukup untuk klien. Campuran yang tepat dari konselor respon dan mendengarkan adalah salah satu perilaku konselor yang paling sulit untuk belajar. ${ }^{8}$

a. Makna dan Penanganan Keheningan Klien (The Meaning and Handeling of Client Silence)

Dalam mengevaluasi signifikansi jeda, waktu kejadian dan apakah itu diprakarsai oleh klien atau konselor yang signifikan. Intitated lama jeda oleh klien pada awal wawancara awal menyampaikan arti yang berbeda untuk konselor dari satu terjadi kemudian dalam proses. Jeda yang dibuat oleh klien pada awal wawancara mungkin mencerminkan rasa malu atau perlawanan. Pada berlangsung konseling, keheningan secara bertahap datang sebagai media komunikatif bersemangat untuk dukungan, ekspresi emosi dan pikiran.

Selain itu, harus ditekankan bahwa wawancara konseling dicirikan oleh

\footnotetext{
${ }^{8}$ Brammer, L.M \& Shostrom, E.L. 1982. Therapeutic Psikology Fundamentals of Counseling and Psychotherapy, New Jersey: Prentice-Hall.Inc. hal 250
} 
jeda dari berbagai panjang dari beberapa detik hingga beberapa menit. Sulit untuk menilai makna dari semua jeda dan tidak dalam usaha di sini untuk Katalog kemungkinan ini. Berikut ditawarkan hanya sebagai saran untuk menafsirkan dan penanganan wawancara keheningan yang diprakarsai oleh konselor atau klien.

Setiap diskusi tentang keheningan memerlukan bahwa pengakuan diberikan kepada dua jenis: negatif atau menolak, dan positif dan menerima. Makna kedua keheningan adalah bahwa klien atau konselor telah reaced akhir ide dan hanya wondering what katakan selanjutnya. Arti yang ketiga keheningan adalah resistensi termotivasi permusuhan atau kecemasan yang memotivasi embrrassment. Berhenti dengan keempat berarti mungkin sinyal bahwa klien mengalami beberapa perasaan menyakitkan khususnya yang dia atau dia tidak siap untuk verbalisasi.

Arti kelima keheningan mungkin diberi label sebagai "antisipatif" dimana klien berhenti mengharapkan sesuatu dari konselor beberapa kepastian, informasi, atau interpretasi. Arti keenam klien berhenti adalah bahwa mereka mungkin thingking atas apa yang telah mereka katakan. Akhirnya, jeda mungkin berarti bahwa klien hanya pulih dari kelelahan ekspresi emosional yang sebelumnya. ${ }^{9}$

b. Nilai-Nilai Konselor Mendengarkan (Values of Counselor Listening)

Ini adalah salah satu asumsi dasar kami bahwa mendengarkan jenis positif dan menerima adalah teknik konseling yang paling menjanjikan. Konselor keheningan memaksa klien untuk berbicara. Nilai yang kedua, menekankan dari penelitian dengan teknik Rorschard, menunjukkan bahwa introversive orang mungkin individu sangat kreatif, dengan kehidupan batin yang kaya. Mereka harus tidak perlu dilihat sebagai orang-orang yang lebih rendah daripada individu ekstrover lebih sosial dihargai. Dalam konseling. Klien menemukan bahwa mereka dapat diam dan masih disukai. Mungkin itu adalah penerimaan ini keheningan di klien yang memberikan kurang mengartikulasikan orang perasaan yang layak dan dengan demikian membantu orang untuk menerima diri mereka sendiri untuk apa yang mereka.

Nilai-nilai konselor mendengarkan ketiga adalah bahwa, setelah yang signifikan ekspresi perasaan, klien diperbolehkan untuk berpikir dan untuk datang dengan kesadaran yang mendalam. Nilai keempat konselor mendengarkan adalah bahwa mengurangi kecepatan wawancara. Sering konselor Indra bahwa klien bergegas, atau bahwa konselor merasa dipaksa untuk mendorong keras. ${ }^{10}$

\footnotetext{
${ }^{9}$ Ibid, hal 250

${ }^{10}$ Ibid, hal 250
} 
c. Kesulitan dalam Menggunakan Teknik Mendengarkan (Difficulties in Using Listening Techniques)

Dalam pelatihan konseling psikolog, kami telah menemukan bahwa ia telah diperlukan untuk mengajarkan toleransi keheningan klien tanpa rasa malu. Belum dicoba terapis menit keheningan tampaknya seperti satu jam. Menggunakan teknik mendengarkan tidak berarti menjadi pasif atau uncommunicative, namun.

Salah satu aspek yang paling sulit menggunakan teknik mendengarkan adalah menjaga diam ketika klien untuk berbicara. Sebagian besar dari klien bicara, namun, ini tidak selalu indikator hubungan kerja yang lebih efektif.

Hubungan antara rasio wawasan dan bicara dalam studi di atas yang dapat disimpulkan; Meskipun, dengan studi keterampilan wawancara, wawasan cenderung dikaitkan dengan frekuensi rendah klien bicara. Dengan kata lain, ketika konselor menjelaskan hal-hal dalam belajar keterampilan wawancara, klien rupanya mendapat masalah, Garners dan Robinson menemukan bahwa itu bukan jumlah klien per se bicara yang berkaitan dengan kesadaran, tapi agak relatif jumlah klien bicara dalam kerangka dari gaya konseling tertentu. Dengan kata lain, tetap diam dan hanya mendapatkan klien untuk berbicara lebih banyak tidak akan selalu mengarah ke kesadaran yang lebih besar. Seorang konselor dapat berbicara dengan banyak atau terlalu sedikit di waktu yang salah. ${ }^{11}$

\section{1) Menetapkan Tujuan}

Menetapkan tujuan adalah aktivitas konselor mendorong konseli menyadari kebutuhan memperoleh bantuan sehingga menyepakati perilaku yang akan dibicarakan dalam proses konseling.

\section{2) Penstrukturan}

Pada proses konseling kadang-kadang terjadi pembicaraan yang meluas baik dari sisi konseli maupun dari sisi konseling. Pembatas/kontrak diperlukan, mencakup pembatasan/kontrak waktu, masalah, peran, dan tindakan. Tujuan penstrukturan adalah agar konselor dan konseli memahami perannya masingmasing, mengetahui berapa lama sesi konselor akan diselenggarakan , membatasi masalah yang akan dibahas, memahami apa yang akan dilakukan dan apa yang diharapkan dalam sesi konseling.

Tujuan penstrukturan adalah untuk menjelaskan peranan konselor, peranan klien dan proses konseling yang akan dijalani oleh klien. Isi/materi dari penstrukturan meliputi:

a) Apa itu konseling?

b) Bagaimana konseling itu dilakukan?

c) Kemana arah konseling itu dilakukan? 
d) Asas-asas pokok yang menangui proses konseling?

e) Peran konselor dan klien dalam proses konseling?

Penstrukturan dalam konseling terbagi atas dua macam, yaitu:

a) Penstrukturan penuh, yaitu semua isi/materi penstrukturan disampaikan kepada klien yang belum memahami damn mengetahui apa itu konseling. $\mathrm{Hal}$ ini dilakukan untuk klien yang tidak menyadari dirinya bermasalah dan klien punya persepsi negatif terhadap konseling.

b) Penstrukturan sebagian, yaitu menyampaikan sebahagiaan isi/materi penstrukturan kepada klien. Isi/materi penstrukturan dapat dipilih oleh konselor sesuai kebutuhan klien. Penstrukturan sebagian ditunjukkan untuk klien yang datang secara sukarela yang secara umum sudah memiliki pengetahuan minimal tentang konseling atau sudah perna melakukan konseling. Penstrukturan sebagian dilakukan konselor untuk menata kembali pikiran/perasaan klien tentang konseling.

Kedalaman dan volume dan kapan penstrukturan dilaksanakan, disesuaikan dengan kondisi pemahaman, wawasan, persepsi, dan sikap klien terhadap pelayanan konseling pada umumnya.

\section{Responding}

a. Dorongan Minimal

Dorongan minimal adalah Keterampilan untuk memberikan suatu dorongan langsung yang singkat terhadap apa yang telah dikemukakan konseli. Misalnya dengan menggunakan ungkapan: oh..ya..lalu..terus..dan... ${ }^{12}$ Tujuan dorongan minimal agar konseli terus berbicara dan dapat mengarah agar pembicaraan dapat mencapai tujuan. Dorongan minimal diberikan pada saat konseli akan mengurangi atau menghentikan pembicaraannya dan pada saat konseli kurang memusatkan pikirannya pada pembicaraan atau pada saat konselor ragu atas pembicaraan konseli.

\section{1) Refleksi}

Refleksi adalah Keterampilan konseling untuk menangkap perasaan, pikiran dan pengalaman konseli kemudian memantulkan kembali kepada konseli tentang perasaan, pikiran, dan pengalaman sebagai hasil pengalaman konselor terhadap perilaku verbal dan non verbalnya. ${ }^{13}$ Tujuan keterampilan merefleksi adalah agar konseli dapat merespon secara tepat dan akurat perasaan, pikiran, dan pengalaman dalam pernyataan konseli.

Terdapat tiga jenis refleksi, yaitu:

${ }^{12}$ Sofyan S. Willis. 2004.Konseling Individual; TeoridanPraktek. Bandung : Alfabeta, Hal

${ }^{13}$ Ibid, Hal 184 
a) Refleksi perasaan, yaitu keterampilan atau Keterampilan untuk dapat menangkap perasaan konseli sebagai hasil pengalaman terhadap perilaku verbal dan non verbal konseli kemudian memantulkan perasaan tersebut kepada konseli.

b) Refleksi pikiran, yaitu Keterampilan untuk menangkap ide, pikiran, dan pendapat konseli sebagai hasil pengalaman terhadap perilaku verbal dan non verbal konseli kemudian memantulkannya pada konseli.

c) Refleksi pengalaman, yaitu Keterampilan untuk menangkap pengalamanpengalaman konseli sebagai hasil pengalaman terhadap perilaku verbal dan non verbal konseli kemudian memantulkannya pada konseli.

Merefleksi perasaan membutuhkan keterampilan, namun hal tersebut dapat dipelajari dengan memahaminya dan melatihnya. refleksi merupakan keterampilan menolong orang dapat dipelajari, biasanya tidak digunakan dalam hubungan antar individu yang sifatnya umum, yang tidak menjalani latihan yang bersifat klinis dan bahkan hanya bisa digunakan pada orang dewasa yang dianggap mampu. Dengan adanya latihan keterampilan berkomunikasi dan penekanan pada kemampuan untuk mendengarkan perasaan, maka refleksi akan menjadi kegiatan yang bersifat harian. Contoh-contoh dalam modeling atau peragaan oleh konselor adalah cara yang efektif untuk membantu klien mengungkapkan perasaannya konseling yang dibutuhkan untuk menbantu klien dalam mengungkapkan perasaannya. ${ }^{14}$

2) Empati

Empati adalah kemampuan untuk memahami secara tepat perasaan, pikiran, dan pengalaman konseli, sehingga konselor dapat merasakan apa yang sedang dirasakan oleh konseli. ${ }^{15}$ Empat tidak dapat dipisahkan dengan attending, artinya tanpa attending, maka tidak ada empati. Untuk melakukan empati maka konselor harus mampu mengosongkan perasaan dan pikiran egoistik, serta harus mampu memasuki dunia dalam konseli. Tujuan empati agar konseli merasa diperhatikan, dipahami, didukung serta dihargai harkat dan martabatnya. Empati membuat konselor menerima konseli sebagaimana adanya, mengerti serta menghargai nilai dan sistem nilai konseli. Konseli tidak bersikap menghakimi, menyalahkan atau membenarkan. Konselor bersikap hormat dan manusiawi terhadap orang lain dan sistem nilai yang dianutnya. Terdapat dua macam empati, yaitu: ${ }^{16}$

a) Empati primer, yaitu bentuk empati yang hanya berusaha memahami perasaan, pikiran, dan keinginan konseli, dengan tujuan agar konseli dapat terlibat dan terbuka.

14 Brammer, L.M \& Shostrom, E.L. 1982. Therapeutic Psikology Fundamentals of Counseling and Psychotherapy, New Jersey: Prentice-Hall.Inc.

${ }^{15}$ Ibid, 161

${ }^{16}$ Ibid, Hal 161 
b) Empati tingkat tinggi, yaitu empati apabila kepahaman konselor terhadap perasaan, pikiran, keinginan serta pengalaman konseli lebih mendalam dan menyentuh konseli karena konselor ikut dengan perasaan tersebut. Keikutan konselor tersebut membuat konseli tersentuh dan terbuka untuk mengemukakan isi hati yang mendalam, berupa perasaan, pikiran, pengalaman termasuk penderitaannya.

Empati bahkan lebih powerfull jika konselor pernah mengalami kejadian yang sama, atau minimal orang terdekat dengan konselor . Ada dua cara agar konselor mampu melakukan dan menghadirkan empati terhadap orang lain, seperti berikut ini :

a) Melatih Perasaan Empati

(1) Menuliskan Perasaan Positif atau Negatif

Cobalah tuliskan kejadian-kejadian yang konselor alami dalam sebuah buku atau catatan, tuliskan dengan sedetail mungkin apa yang konselor rasakan. Setelah menulis itu, coba simpan buku tersebut, kemudian baca lagi buku tersebut setelah beberapa lama. Coba konselor simpulkan perasaan konselor ketika konselor menuliskan tentang kejadian dalam buku tersebut pada kondisi konselor saat ini.

(2) Mendengarkan Curhat Orang Lain

Cobalah mendengarkan cerita teman, saudara, atau orang lain berkaitan dengan perasaannya atau kondisinya saat itu. Simak cerita mereka dan coba konselor simpulkan sendiri tentang perasaan orang tersebut dalam versi konselor .

(3) Membayangkan Kejadian pada Diri Sendiri

Bayangkan bahwa diri konselor adalah seseorang mengalami suatu musibah baik dalam novel, film, berita, atau cerita. Coba konselor simpulkan perasaan yang bagaimana yang dirasakan konselor ketika berada dalam posisi tersebut.'

b) Lakukan Tindakan Empati

(1) Berhati-hati dalam Ucapan dan Perbuatan

Setiap konselor melakukan sesuatu, selalu jagalah sikap konselor terhadap orang lain. Berusaha menjaga perasaan seseorang dapat meningkatkan kepekaan hati dan empati tingkat tinggi yang dapat menggerakkan emosional seseorang.

(2) Mulai dari Diri Sendiri

Selalu menjaga setiap hal yang konselor lakukan seolah-olah itu menjaga diri konselor sendiri. Menginginkan yang terbaik bagi dalam sebuah hal ibaratkan itu untuk diri konselor sendiri, begitu penting dan sangat berarti bagi diri konselor . 


\section{(3) Memberikan Bantuan}

Selalu mulai dengan membantu orang lain, mulailah dari orang terdekat konselor atau keluarga konselor . Biasakan sikap ringan tangan terhadap kesulitan orang lain dan lakukan yang terbaik seolah-olah itu untuk dirimu sendiri.

(4) Paraphrase

Keterampilan paraprase adalah untuk menangkap pesan utama yang disampaikan konseli, kemudian menyatakan kembali dengan kalimat yang mudah dan sederhana dengan bahasa konselor sendiri. ${ }^{17}$ Ada empat tujuan utama paraphrese, yaitu (1) untuk menegaskan pada konseli bahwa konselor bersama konseli, dan berusaha memahami apa yang dikatakan konseli, (2) mengendapkan apa yang dikatakan konseli secara lebih ringkas, (3) memberi arah wawancara konseling, (4) mengecek kembali persepsi konselor tentang apa yang dikemukakan konseli. Kalimat dapat diawali dengan kata "apakah atau tampaknya".

3) Menyimpulkan Sementara

Keterampilan menyimpulkan adalah Keterampilan untuk meringkas atau menyimpulkan apa yang telah dikemukakan konseli pada proses konseling. Keterampilan menyimpulkan sementara bertujuan untuk (1) memberikan kesempatan pada konseli untuk mengambil kilas-kilasi balik (feed back) dari hal-hal yang telah dibicarakan, (2) untuk menyimpulkan kemajuan hasil pembicaraan bertahap, (3) mempertajam fokus pada wawancara konseling. Keterampilan menyimpulkan sementara dapat dilakukan setiap saat yang dipkonselor ng perlu oleh konselor.

4) Menyimpulkan

Pada akhir sesi konseling konselor membantu konseli untuk menyimpulkan hasil pembicaraan sescara keseluruhan yang terkait bagaimana keadaan perasaan konseli saat ini setelah mengikuti proses konseling, dan membantu memantapkan rencana.

\section{Hasil Dan Pembahasan}

Hasil penelitian ini mendeskripsikan kemampuan dan keterampilan dasar konseling yang dimiliki oleh guru kelas di sekolah dasar dalam membantu permasalahan siswa di sekolah. Keterampilan dasar konseling yang diungkapkan yaitu; Keterampilan dasar konseling yaitu: 1) perilaku attending meliputi (a)mendengar aktif (b)menetapkan tujuan dan (c)penstrukturan, 2) responding meliputi: (a)dorongan Minimal (b)Refleksi, (c)empati, (d)paraphrase, (e)menyimpulkan sementara, dan (f)Menyimpulkan. 
Tabel 1

Gambaran Keterampilan Dasar Konseling Guru Sekolah Dasar dalam Membatu Siswa yang Bermasalah di Sekolah

\begin{tabular}{|c|c|c|c|c|}
\hline No & Interval & Kategori & F & $\%$ \\
\hline 1 & $74-83$ & Sangat Tinggi & 7 & 30 \\
\hline 2 & $64-73$ & Tinggi & 5 & 22 \\
\hline 3 & $54-63$ & Sedang & 4 & 17 \\
\hline 4 & $44-53$ & Rendah & 2 & 9 \\
\hline 5 & $34-43 \quad$ Sangat Rendah & 5 & 22 \\
\hline \multicolumn{2}{|c|}{ Total } & 23 & 100 \\
\hline
\end{tabular}

Gambar 1. Keterampilan Dasar Konseling Guru Sekolah Dasar dalam Membatu Siswa yang Bermasalah di Sekolah

\section{Gambaran Dasar Konseling Guru Sekolah Dasar dalam Membatu Siswa yang Bermasalah di Sekolah}

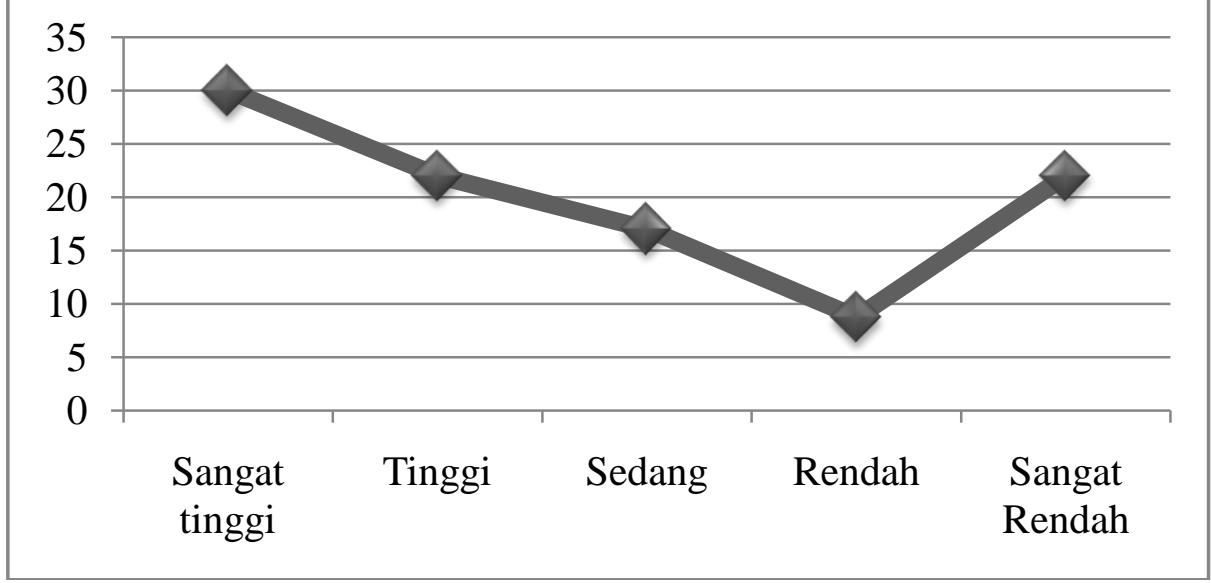

Berdasarkan grafik diatas menunjukkan keterampilan yang dimiliki guru sekolah dasar dalam membantu siswa masih perlu ditingkatkan dan mendapatkan pelatihan. Ada 30\% guru kelas yang sudah memiliki keterampilan dasar konseling untuk membantu permasalahan siswa di sekolah dasar. Keterampilan yang dimiliki guru kelas antara lainKeterampilan dasar konseling yaitu: 1) perilaku attending meliputi (a)mendengar aktif (b)menetapkan tujuan dan (c)penstrukturan, 2) responding meliputi: (a)dorongan Minimal (b)refleksi, (c)empati, (d)paraphrase, (e)menyimpulkan sementara, dan (f)menyimpulkan.

Sebagian kecil dari guru sekolah dasar yang masih memiliki keterampilan yang rendah dalam membantu permslahan siswa. Sebanyak $22 \%$ guru sekolah daasar masih memiliki keterampilan dasar konseling dalah kategori sangat 
rendah dan ada $31 \%$ guru kelas sekolah dasar yang perlu mendapatkan pelatihan dan wokshop untuk meninhgkatkan keterampilanya dalam membatu siswa yang bermasalah di sekolah dasar.

Keberhasilan konseling banyak ditentukan oleh keefektifan konselor dalam menggunakan berbagai Keterampilan. Hubungan antara konselor dan klien merupakan inti proses konseling dan psikoterapi oleh karena itu para konselor hendaknya menguasai berbagai Keterampilan dalam menciptakan hubungan. Terdapat tahap-tahap dalam proses konseling, yaitu antara lain:

Keterampilan Pembukaan (Pengantaran/ introdaktion) Yaitu usaha konselor untuk mengantarkan klien dalam memasuki proses konseling. Dalam Keterampilan pembukaan ini konselor memberikan penjelasan kepada klien tentang konseling dan psikoterapi, tujuan, asas-asas, manfaat serta hal lain yang berhubungan dengan proses konseling dan psikoterapi.

Keterampilan hubungan RefleksiRefleksi perasaan merupakan suatu usaha konselor untuk menyatakan dalam bentuk kata-kata yang segar dan sikap yang esensial (perlu). Refleksi ini merupakan Keterampilan penengah yang bermanfaat untuk digunakan setelah hubungan permulaan dibuat dan sebelum pemberian informasi dan tahap interpretasi dimulai. Perasaan-perasaan yang diekspresikan dapat dikelompokkan kedalam tiga kategori yaitu yang positif, negative, dan ambivalen.

Keterampilan Penerimaan dan Penstrukturan Keterampilan penerimaan merupakan cara bagaimana konselor melakukan tindakan agar klien merasa diterima dalam proses konseling. Dalam Keterampilan penerimaan, ada 3 unsur yaitu antara lain: 1) ekspresi air muka, 2) tekanan suara, 3) jarak dan perawakan.Keterampilan penstrukturan (structuring) adalah proses menetapkan batasan oleh konselor tentang hakekat, batasan-batasan dan tujuan proses konseling pada umumnya, dan hubungan tertentu pada khususnya. Menata stuktur akan memberikan kerangka kerja atau orientasi terapi kepada klien. Struktur konseling mempunyai dua unsure yaitu, pertama, unsure implicit dimana peranan konselor yang secara umum diketahui klien, dan yang kedua, yaitu struktur yng formal berupa pernyataan konselor untuk menjelaskan dan membatasi proses konseling.Dengan demikian structuring merupakan Keterampilan merumuskan batasan dan potensialitas konseling.

Keterampilan MendengarkanMendengarkan merupakan dasar bagi semua wawancara. Kegiatan ini menghendaki agar penyuluh lebih banyak diam dan menggunakan semua indranya untuk menanggap semua pesan.Dengan telinganya konselor mendengarkan kata-kata yang diucapkan dan tekanan suara dari klien; dengan pikirannnya dia menanghkap isi pesan yang disampaikan, dan dengan matanya dia mengamati bahasa badani dalam sikap duduk, gerak gerik, isyarat dan sebaginya yang ditampilkan oleh klien. Konselor juga mendengarkan diri nya sendiri, dia mencatat tangapannya sendiri terhadap pesan yang diterima 
dari klien, dan bagaimana konselor menyesuaikan diri terhadap pesan-pesan itu.Mendengarkan secara aktif dan tepat adalah amat penting selama wawancara berlangsung, lebih-lebih pada saat permulaan ketika konselor biasanya mengambil bagian secara verbal kurang aktif. Konselor berusaha secara benarbenar tepat penyesuaian dirinya dengan diri orang lain, memusatkan diri pada orang lain, dan menjadikan pesan-pesan yang datang dari oarng lain itu sebagai suatu yang amat penting.

Keterampilan MengarahkanPemberian pengarahan mengubah tekad hubungan konseling dan psikoterapi. Di sini konselor lebih berinisiatif dari pada klien. Dengan memberikan pengarahan, konselor merasa lebih terpanggil untuk diskusi dari pada klien, dan secara tidak langsung konselor mengetahui apa yang harus dilakukan. Pemberian pengarahan hanya dilakukan bila mana konselor benar-nenar telah memahami keadaan dan kebutuyhan klien. Nilai dari upaya pemberian pengarahan tidaklah diragukan ; namun konselor harus menentukan kapan cara ini tepat dilakukan, dan cara mana yang sebaiknya dipakai.Ada akibat-akibat (yang kurang mengenakkan) tertentu yang berkaitan menggunakan pengarahan. Kebanyakan para pemberi bantuan telah cukup mengenal keterampilan ini sebelumnya. Oleh karena itu, terdapat kecendrungan untuk menggunakannya secara berlebih-lebihan atau cepat-cepat menggunakan cara ini dalam setiap suasana konseling dan psikoterapi yang sulit. Penggunaan pengarahan yang terlalu cepat atau terlalu sering terhadap klien yang enggan malhan dapat mengakibatkan timbulnya suasana risi(tidak tenang) aau menjngkelkan pada diri klien dan penyuluh tampak kurang peka terhadap suasana kejiwaan klien.

Keterampilan mengakhiri proses konselingKetrampilan mengakhiri wawancara konselng merupakan Keterampilan hubungan dalam proses konseling. Mengakhiri wawancara, dapat dilkukan dengan Membuat catatan merupakan usaha sederhana tetapi sangat penting karena kegiatan ini mempunyai andil yang sangat besar dalam rencana pengubahan tingkah laku yang perlu dirubah.

\section{Kesimpulan}

Dari hasil penelitian dapat disimpulkan secara umum Ada 30\% guru kelas yang sudah memiliki keterampilan dasar konseling untuk membantu permasalahan siswa di sekolah dasar. Keterampilan yang dimiliki guru kelas antara lain Keterampilan dasar konseling yaitu: 1) perilaku attending meliputi (a)mendengar aktif (b)menetapkan tujuan dan (c)penstrukturan, 2) responding meliputi: (a)dorongan Minimal (b) Refleksi, (c)empati, (d)paraphrase, (e)menyimpulkan sementara, dan (f)Menyimpulkan.Sebanyak $22 \%$ guru sekolah daasar masih memiliki keterampilan dasar konseling dalah kategori sangat rendah dan ada $31 \%$ guru kelas sekolah dasar yang perlu mendapatkan pelatihan dan wokshop untuk meninhgkatkan keterampilanya dalam membatu siswa yang bermasalah di sekolah dasar. 


\section{Daftar Pustaka}

Berg Robert C, Landrent Garry L \& Kevin A. Fall. 2006. Group Counseling Concepts and Procedures. New York. Published in Great Britain byRoutledge Taylor \& Francis Group

Brammer, L.M \& Shostrom, E.L. 1982. Therapeutic Psikology Fundamentals of Counseling and Psychotherapy, New Jersey: Prentice-Hall.Inc.

Corey, M. S., Corey, G., \& Corey, C. (2009). Groups: Process and practice (8th ed.). PacificGrove, CA: Brooks/Cole.

Jacobs E, Masson Robert L \& Harvill Riley L. \& Schimmel Christine. (2012). Group Counseling Strategies and Skills. West Virginia University.Brooks/Cole, Cengage Learning. Publisher: Linda SchreiberGanster.

Kementrian Pendidikan dan Kebudayaan. (2014). Permendikbud No 111 Tahun 2014 tentang Penyelengaraan Bimbingan dan Konseling di Sekolah Dasar dan Menengah, Direktorat Jendral Guru dan Tenaga Kependidikan: Jakarta

Komalasari, G., Eka, W., \& Karsih. (2011). Teori dan Keterampilan Konseling. Jakarta: Indeks.

Natawidjaja, Rochman. (2009). Konseling Kelompok Konsep Dasar dan Pendekatan, Bandung. Rizqi Press.

Netrawati, Khairani, Yeni Karneli. (2018). Upaya Guru BK untuk Mengentaskan Masalah-masalah Perkembangan Remaja dengan Pendekatan Konseling Analisis Transaksional. Jurnal Islamic Counseling; Bimbingan Konseling Islam., Vol. 2. 1.

Rusmana, Nkonselor ng. (2009). Bimbingan dan Konseling Kelompok di Sekolah (Metode, Keterampilan dan Aplikasi). Bandung. Rizqi Press

Rusmana, Nkonselor ng. (2009). Konseling Kelompok Bagi Anak Berpengalaman Trauma. Bandung. Rizqi Press

Sofyan S. Willis. (2004).Konseling Individual; Teori dan Praktek. Bandung : Alfabeta.

Suharsimi Arikunto. (2010). Prosedur Penelitian Suatu Pendekatan Praktis. Jakarta: Rhineka Cipta. 